\title{
The role of the irrigation network in the efficient use of water
}

\author{
Bakhtiyar Matyakubov ${ }^{1 *}$, Davronbek Yulchiyev ${ }^{1}$, Isomiddin Kodirov $^{2}$, and Gulnoroy \\ Axmedjanova ${ }^{1}$ \\ ${ }^{1}$ Tashkent Institute of Irrigation and Agricultural Mechanization Engineers, Tashkent, Uzbekistan \\ ${ }^{2}$ Karshi Engineering-Economics Institute, Tashkent, Uzbekistan
}

\begin{abstract}
The article highlights the unique role of irrigation canals in the supply of water in the required amount, depending on crop demand and the rational use of it. The study of the prevention of filtration in irrigation networks and the study of the existing malfunctions in the operation of irrigation networks, the sequence of works on the repair of irrigation networks were analyzed, and the priority of repair work was determined. The current state of the Khumbuz canal in Khiva, Khorezm region of the Republic of Uzbekistan was studied. Information was obtained and analyzed on compliance with design specifications during construction and the presence of protection zones in the canal design. Analytical indicators have been developed to extend the service life of the Khumbuz canal to ensure its normal operation and supply the required amount of water to crops. In the implementation of water supply to agricultural crops, priority is given to the repair and construction of hydraulic structures, including the Khumbuz canal. In addition, all the work to be done was planned based on the priority of the work. It has been found that the amount of water required to irrigate crops can be achieved uniformly along the length of the canal, at the top, middle, and bottom of the canal, by ensuring that the irrigation networks operate at the required level. Specific scientific recommendations have been given for the normal operation of the Khumbuz canal. Repairing the canal has been shown to increase water use by 20 percent and increase crop yields by 15 percent by ensuring that crops receive the required amount of water on time. The service area of the Khumbuz canal is 1.460 hectares. The length of the canal to be repaired is $6 \mathrm{~km}$. of which 2,568 km of new concrete. The maximum water flow of the canal is $2.5 \mathrm{~m}^{3} / \mathrm{sec}$, and the normal water flow is $2.0 \mathrm{~m}^{3} / \mathrm{sec}$. The efficiency of the channel (canal) is 0.93 . The article provides information on how to achieve efficient use of irrigation water by repairing hydraulic structures at the required level and the construction of new ones.
\end{abstract}

\footnotetext{
*Corresponding author: bmatakubov@inbox.ru and b.matyakubov@tiiame.uz
} 


\section{Introduction}

"Improving the efficiency of agricultural production, the widespread introduction of intensive technologies and innovative developments, ensuring food security of the country," mentioned in Section 3.13 of the "Priorities of Economic Development" established by the Decree of the President of the Republic of Uzbekistan No. PF-5953 of March 2, 2020 "Improvement of reclamation of irrigated lands, ensuring safe and stable operation of irrigation and reclamation facilities, rational and economical use of water resources" on "Further development and reform of the cluster system and deep processing of agricultural products in all directions." Ensuring the implementation of the Resolution of the Cabinet of Ministers of the Republic of Uzbekistan, dated October 19, 2019, No. 673 "On measures to improve the system of resource management" No. PP-4486 of October 9, 2019, and Khorezm region in 2019-2022 Measures for the integrated development of the city of Khiva, as well as resolutions of the Cabinet of Ministers of the Republic of Uzbekistan dated November 19, 2020, No. 145 it was determined that the implementation of the statement of the presidium meeting was a priority. This, in turn, requires a high level of implementation of the use of hydraulic structures.

Approved by the Decree of the President of the Republic of Uzbekistan, dated February 12, 2018 PF-5330 "On organizational measures to radically improve the system of public administration of agriculture and water management" and July 10, 2020 PF-6024. "Development of water management of the Republic of Uzbekistan 2020. The priorities set out in the " Concept for 2030" include: improving the water resources management system, as well as ensuring the safety of hydraulic structures, accelerating the construction and reconstruction of hydraulic structures and other water bodies, improving the system of water resources accounting; Along with the modernization of the security system of water facilities, the introduction of modern information and communication and innovative technologies in the industry is planned $[1,2]$.

Several scientists on the repair of irrigation networks, control over the operation, design, and operation of hydraulic structures, including Balla D., Omar M., Rozanov N., Uralov L., Hikoya L., Bozorov D., Bakiev M., Yangiev A., Khamidov M., Isabaev K., Matyakubov B., Xamidov A., Imomov S. and others have conducted research [3 - 9, 13-18].

The scientists mentioned above have conducted several important scientific studies and made recommendations to assess the performance of irrigation networks at the required level, prolong their service life and assess the structural safety of hydraulic structures and their impact on human life.

Scientists have not researched the problems observed in the operation of irrigation canals at the required level, i.e., the reduction of damage and damage to hydraulic structures in the canal, as well as safety criteria.

With this in mind, the research was carried out considering the problems observed in the study of the canal "Khumbuz" at the level of service, i.e., safety criteria to reduce the breakdown and damage to hydraulic structures in the canal.

Engineering work was carried out on the technical condition of existing hydraulic structures along the length of the canal, the assessment of the condition of the canal along the length of the canal and the elimination of hazards in the canal, the demolition and decommissioning of existing structures.

The main problem in the article is the high water loss in the Khumbuz canal and the technical condition of hydraulic structures and the fact that the canal cover does not meet the required level. The technical condition of the Khumbuz canal is because the existing dams in the water distribution system do not work at the required level and the turbidity in the canal is not well cleaned, there is no water metering facility, but it does not work at the required level. It is considered that the water is not evenly distributed in the upper-middle 
and lower part of the canal length, and modern irrigation technologies are not used $[10,11$, $12]$.

The study's main purpose is to analyze the operation of the irrigation canal and the technical condition of existing hydraulic structures and provide specific recommendations for reliable, safe operation.

The following tasks must be performed to achieve the goals:

- Study the current state of the canal along its entire length;

- Study of the technical condition of hydraulic structures in the canal;

- Analysis of damage to hydraulic structures;

- Analysis of the situation with turbidity in the canal and specific recommendations for prevention;

- Detection of breakdowns of hydraulic structures in the canal;

- Development of conclusions on the reliable and safe operation of hydraulic structures in the canal.

\section{Methods}

In the course of the research, statistical data analysis methods were used to assess the condition of the canal and the technical condition of the existing hydraulic structures, to determine and evaluate the criteria for the safe operation of the canal and its hydraulic structures.

\section{Results and Discussions}

The research aims to improve the canal banks passing through the city of Khiva and improve the water supply of irrigated lands through the canal. Based on this, we will focus on the main indicators of the Khumbuz channel.

- The canal was built and commissioned in 1946.

- Service area: 1460 ha.

- Total length of the canal: $6 \mathrm{~km}$, of which $1.05 \mathrm{~km}$ is concrete coating.

- Maximum water capacity of the canal: $2.5 \mathrm{~m}^{3} / \mathrm{sec}$.

- Normal water flow capacity of the canal: $2.0 \mathrm{~m}^{3} / \mathrm{sec}$.

- The design efficiency of the channel: 0.93 .

- The following is a schematic of the location of the channel (Figures 1). 


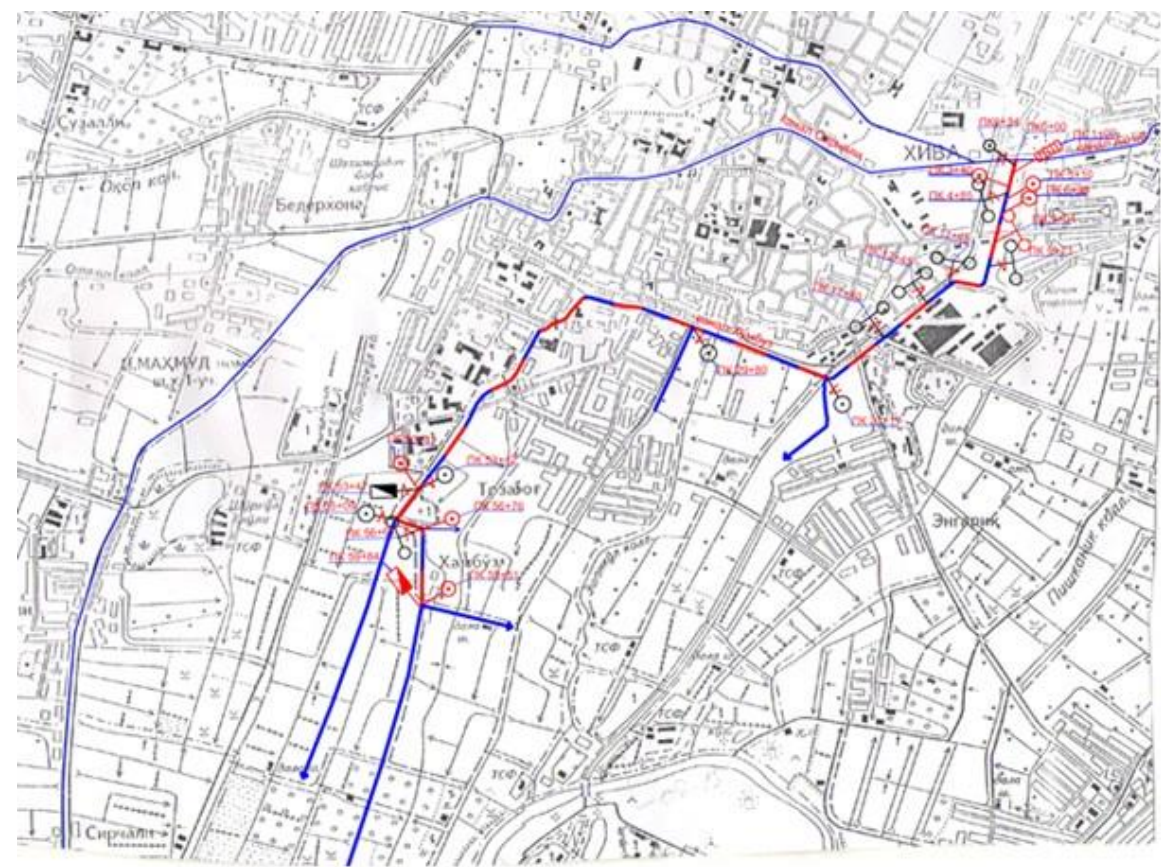

Fig. 1. Layout of the Khumbuz canal (Legend: red is rehabilitated sections of the canal and structure).

So far, 2,568 $\mathrm{km}$ of the canal have been repaired along the length of the canal. Reconstruction of 22 sections of 22 different types of hydraulic structures has become obsolete due to obsolescence. The efficiency of domestic canals is 0.72 , according to the district irrigation department. It's too small. As a result of muddy sedimentation on the sides and bottom of the canal, the water permeability has significantly decreased, and there are problems with the supply of water required for crops.

As a result, water management has become more difficult, the water supply to irrigated lands from the canal has deteriorated, and it has become difficult to supply water to irrigated areas at the end of the canal.

As a result of implementing these measures, the water supply of agricultural crops will be improved, and crop yields will increase.

Many years of engineering and geological research materials obtained by Uzgiprovodkhoz and Uzsuvloyikha institutes were used to determine the research's soil and engineering geological conditions.

The following data were used in the research:

1. Topographic and geodetic works performed by Khorezmsuvloyiha Limited Liability Company;

2. Long-term engineering and geological materials of Uzgiprovodkhoz and Uzsuvloyikha institutes were used.

3. Data on groundwater levels and salinity performed by the Hydrogeological Reclamation Expedition of Khorezm region;

4. Data of Irrigation district department of Khiva district;

5. The research was conducted based on current construction standards and documents.

Based on the above data and field research, the reasons for the failure of the canal and its hydraulic structures were developed to assess the reliable and safe operation of the canal and its hydraulic structures.

The main types of technical failures of the Khumbuz canal are as follows (Figure 1):

- Non-compliance and malfunction of the channel. 
- Technical condition of GTI in the channel is not at the required level.

- Decreased canal capacity.

- Violation of the operating mode.

- Construction defect.

- High water loss.

- Shortcomings in the project

In addition to the above, the technical failure of the Khumbuz canal is mainly due to the failure of the canal users to maintain the water in a timely manner (see Figure 2).

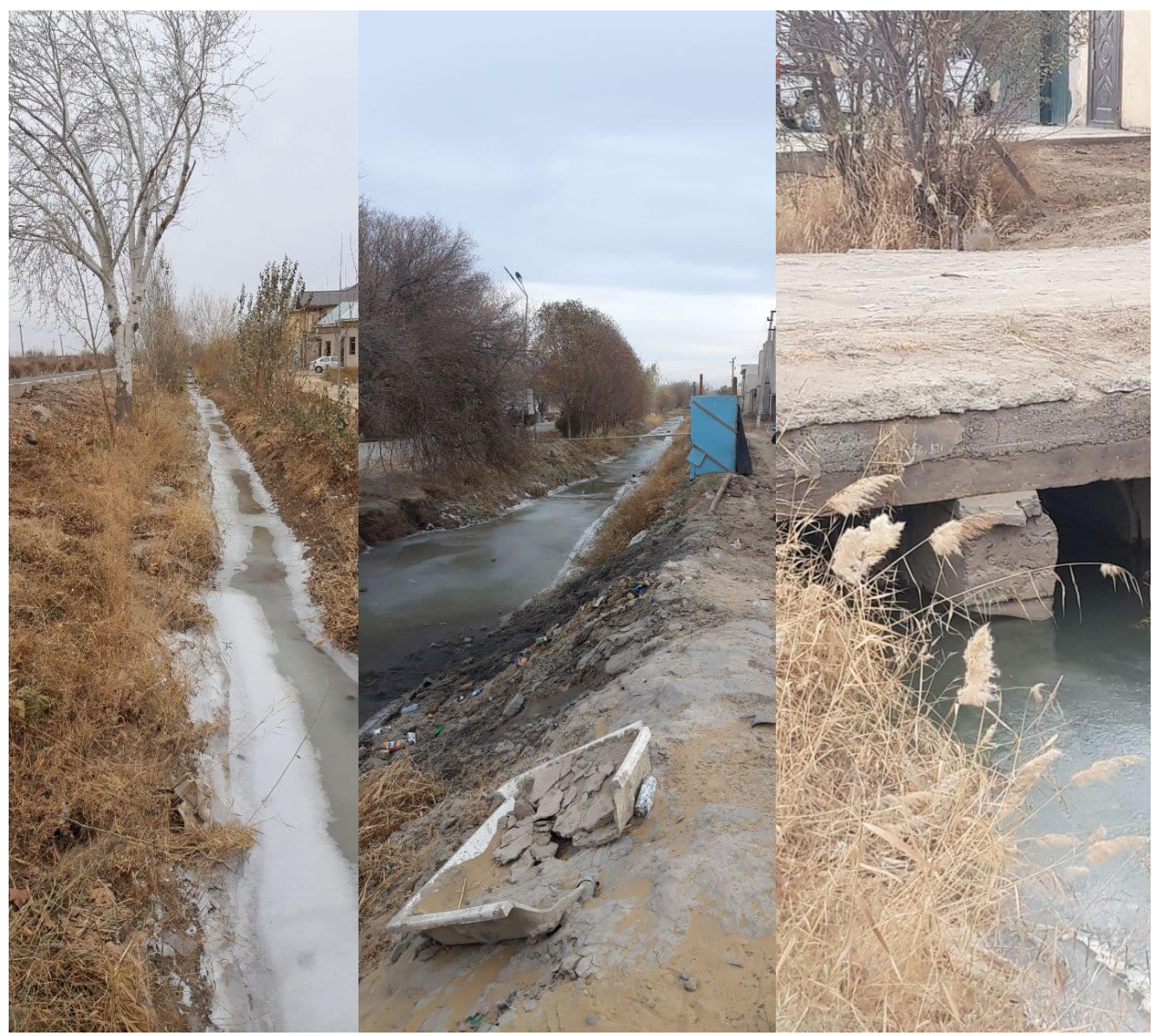

Fig. 2. Technical condition of Khumbuz canal

In determining the gross water consumption of the canal, the loss of canal water to the soil at a distance of $1 \mathrm{~km}$ is determined by the following formula following Building regulations 2.06.03-97 in land channels:

$$
Q_{f}=0.0116 \cdot K_{f} \cdot \mu \cdot\left(B+2 \cdot d_{c}\right)
$$

Here: $Q_{f}$ is water consumption per $1 \mathrm{~km}$ of absorption, $\mathrm{m}^{3}$ per sec;

$K_{f}$ is the filtration index of the channel, m per day $\left(\mathrm{K}_{\mathrm{f}}=0.3 \mathrm{~m} /\right.$ day);

$B$ is the width of the channel along the water surface, $\mathrm{m}$; 
$d_{c}$ is the water depth in the canal, m; bottom.

$\mu$ is an indicator of the depth of water in the channel, the width, and the slope of the

The loss of absorption in the concrete part of the channel was determined as follows:

$$
Q_{f}=0.0116 \cdot \frac{K_{f}}{t} \cdot\left[d_{c}+t+2 \cdot d_{c}\left(\frac{d_{c}}{2}+\frac{m_{t}}{\sqrt{1+m^{2}}}\right)\right] \cdot \sqrt{1+m^{2}}
$$

Where: $Q_{f}$ is channel screen filtration indicator;

$t$ is the thickness of the concrete coating, $\mathrm{m}$;

$d_{c}$ is the water depth in the canal, $\mathrm{m}$;

$m$ is the lateral slope index.

The water consumption determined and received using the above calculations is given in table 1 below:

Table 1. Estimated water consumption of Khumbuz canal

\begin{tabular}{|c|c|c|c|c|c|c|c|c|}
\hline \multirow{2}{*}{\multicolumn{2}{|c|}{$\begin{array}{l}\text { Hydraulic section, } \\
\text { channel view }\end{array}$}} & \multirow{2}{*}{$\begin{array}{c}\text { Sectio } \\
\mathrm{n} \\
\text { length } \\
, \mathrm{km}\end{array}$} & \multirow{2}{*}{$\begin{array}{c}\text { Network } \\
\text { s } \\
\text { water } \\
\text { consum } \\
\text { ptionm }{ }^{3} / \\
\text { s }\end{array}$} & \multirow{2}{*}{$\begin{array}{c}\text { At the } \\
\text { beginnin } \\
\mathrm{g} \text { of the } \\
\text { chapter } \\
\text { water } \\
\text { consum } \\
\mathrm{ption} \\
\mathrm{m}^{3} / \mathrm{s}\end{array}$} & \multicolumn{2}{|c|}{$\begin{array}{l}\text { Filtration } \\
\text { lose }\end{array}$} & \multirow{2}{*}{$\begin{array}{l}\text { Calculated } \\
\text { at the end } \\
\text { of the } \\
\text { section } \\
\text { water } \\
\text { consumpti } \\
\text { on } \mathrm{m}^{3} / \mathrm{s}\end{array}$} & \multirow{2}{*}{$\begin{array}{c}\text { Accepte } \\
\mathrm{d} \text { water } \\
\text { consum } \\
\text { ption } \\
\mathrm{m}^{3} / \mathrm{s}\end{array}$} \\
\hline & & & & & $1 \mathrm{~km}$ & total & & \\
\hline \multicolumn{2}{|c|}{ After PK* $60+00$} & & 0.329 & & & & & \\
\hline $\begin{array}{c}51+70 \div \\
60+00 \\
\end{array}$ & earthy & 0.83 & 0.105 & 0.329 & 0.044 & 0.036 & 0.47 & 0.5 \\
\hline $\begin{array}{c}32+64 \div \\
51+70 \\
\end{array}$ & earthy & 1.906 & 0.187 & 0.47 & 0.05 & 0.095 & 0.752 & 0.8 \\
\hline $\begin{array}{c}21+17 \div \\
32+64\end{array}$ & concrete & 1.147 & 0.224 & 0.752 & 0.02 & 0.022 & 0.998 & 1.0 \\
\hline $\begin{array}{c}0+00 \div 2 \\
1+17 \\
\end{array}$ & concrete & 2.117 & 0.866 & 0.998 & 0.02 & 0.042 & 1.906 & 2.0 \\
\hline
\end{tabular}

*PK (The station) is the distance from the beginning of the channel in $100 \mathrm{~m}$ steps.

The length of the reconstructed canal is $6.0 \mathrm{~km}$. Of this, $2,568 \mathrm{~km}$ will be re-concreted. Monolithic concreting of the channel in the form of a trapezoid with a width of $1.5 \mathrm{~m}$ is provided in the range of PK $0+00$ to PK10 +17 , PK $10+96$ to PK $17+50$, PK18 +72 to PK25 + 68. In this case, the thickness of the concrete coating was assumed to be $10 \mathrm{sm}$.

Based on the existing conditions of the canal, the gallery-type bottom was adopted in the form of a concrete box with a width of $3 \mathrm{~m}$.

According to the surface relief, the slope of the canal was selected, taking into account the elevation marks of the existing hydraulic structures. The canal route is located on sandy soils. The lateral slopes of the channel were assumed to be $\mathrm{m}=1.5$ (Table 2). The channel parameter was selected based on the available cross-sectional dimensions of the channel, water consumption, and water level. The hydraulic elements of the channel were adopted as follows. In the concrete part of the canal, the height of the dam surface was taken into account, taking into account the water level of the dam.

Table 2. Hydraulic elements of "Khumbuz" channel

\begin{tabular}{|c|c|c|c|c|c|c|c|c|}
\hline Intervals & $\begin{array}{c}\text { Water } \\
\text { consumption }\end{array}$ & $\begin{array}{c}\mathrm{Q}, \\
\mathrm{m} / \mathrm{s}\end{array}$ & $\begin{array}{c}\mathrm{B}, \\
\mathrm{m}\end{array}$ & $\mathrm{m}$ & $\mathrm{n}$ & $\mathrm{i}$ & $\mathrm{h}, \mathrm{m}$ & $\begin{array}{c}\mathrm{V}, \\
\mathrm{m} / \mathrm{s}\end{array}$ \\
\hline
\end{tabular}




\begin{tabular}{|c|c|c|c|c|c|c|c|c|}
\hline \multirow{3}{*}{$\begin{array}{l}\text { PK } 0+00 \div \\
\text { PK } 21+20\end{array}$} & \multirow{3}{*}{$\begin{array}{c}\text { maximum } \\
\text { normal } \\
\text { minimal }\end{array}$} & Qmax $=2.4$ & \multirow{3}{*}{1.5} & \multirow{3}{*}{1.5} & \multirow{3}{*}{0.017} & \multirow{3}{*}{0.00015} & 1.25 & 0.57 \\
\hline & & Qnor $=2.0$ & & & & & 1.14 & 0.54 \\
\hline & & Qmin $=0.8$ & & & & & 0.72 & 0.43 \\
\hline \multirow{3}{*}{ 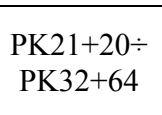 } & \multirow{3}{*}{$\begin{array}{c}\text { maximum } \\
\text { normal } \\
\text { minimal }\end{array}$} & Qmax $=1.2$ & \multirow{3}{*}{1.5} & \multirow{3}{*}{1.5} & \multirow{3}{*}{0.017} & \multirow{3}{*}{0.00015} & 0.89 & 0.48 \\
\hline & & Qnor $=1.0$ & & & & & 0.81 & 0.45 \\
\hline & & $\mathrm{Qmin}=0.4$ & & & & & 0.50 & 0.35 \\
\hline \multirow{3}{*}{$\begin{array}{c}\text { PK32+64 } \div \\
\text { PK43+35 }\end{array}$} & \multirow{3}{*}{$\begin{array}{c}\text { maximum } \\
\text { normal } \\
\text { minimal }\end{array}$} & Qmax $=1.0$ & \multirow{3}{*}{1.0} & \multirow{3}{*}{1.5} & \multirow{3}{*}{0.017} & \multirow{3}{*}{0.00025} & 0.81 & 0.55 \\
\hline & & Qnor $=0.8$ & & & & & 0.73 & 0.52 \\
\hline & & Qmin $=0.3$ & & & & & 0.45 & 0.40 \\
\hline \multirow{3}{*}{ 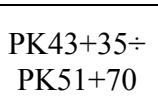 } & \multirow{3}{*}{$\begin{array}{c}\text { maximum } \\
\text { normal } \\
\text { minimal }\end{array}$} & Qmax $=1.0$ & \multirow{3}{*}{1.0} & \multirow{3}{*}{1.5} & \multirow{3}{*}{0.017} & \multirow{3}{*}{0.00025} & 0.81 & 0.55 \\
\hline & & Qnor $=0.8$ & & & & & 0.73 & 0.52 \\
\hline & & $\mathrm{Qmin}=0.3$ & & & & & 0.45 & 0.40 \\
\hline \multirow{3}{*}{ 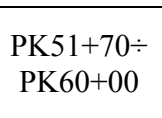 } & \multirow{3}{*}{$\begin{array}{c}\text { maximum } \\
\text { normal } \\
\text { minimal }\end{array}$} & Qmax $=0.6$ & \multirow{3}{*}{1.0} & \multirow{3}{*}{1.5} & \multirow{3}{*}{0.0225} & \multirow{3}{*}{0.00025} & 0.73 & 0.39 \\
\hline & & Qnor $=0.5$ & & & & & 0.67 & 0.38 \\
\hline & & Qmin $=0.2$ & & & & & 0.42 & 0.29 \\
\hline
\end{tabular}

The reliability assessment of the Khumbuz channel is based on the theory of complex system reliability. Failure leads to the synthesis of parametric reliability solutions in the general case, taking into account unexpected factors during the construction process. In the construction of failures, a logical connection is established between the cause of the main event (technical failure of the Khumbuz canal) - the consequences, and the main factors that cause it.

It is necessary to analyze the damage to the Khumbuz canal, the failure of hydraulic structures and the cause of the accident, and the development of errors.

In calculating the reliability of the structure in the channel, it is divided into separate structures - constituent elements. The calculation is performed according to the established quantitative characteristics of the failures of the individual elements of the series, from simple to complex.

Since irrigation systems depend on the failure of hydraulic structures, it may even occur due to the failure of one element of the structure [5].

The law of variation of the probability of failure of elements of hydraulic structures can be described in the form of graphical connections obtained from the results of external surveys and operational data on-site. Based on these connections, the distribution of the probability of failure of building elements (such as continuous random variables) $F(t)$ obeys the normal law (Gauss's law) (1).

$$
F(x)=e^{-\frac{(t-1)^{2}}{0,3183}}
$$

where $t$ is the service life of the elements of the hydraulic structure.

The working and faulty condition of the structure consists of inverse events, and the following equation must be fulfilled (2).

$$
\mathrm{P}(t)+F(t)=1
$$

where, $\mathrm{P}(\mathrm{t})$ is the non-rejection of the hydraulic structure;

$\mathrm{F}(\mathrm{t})$ is the probability of failure of hydraulic structures.

The probability of operation of hydraulic structures without failure during the time interval from 0 to t0 $t$ is determined statistically as follows (3): 


$$
\mathrm{P}\left(t_{0}\right)=1-\frac{n(t)}{N_{0}}=1-F(t)
$$

where $n(t)$ is the number of buildings, elements rejected over time $t$.

The technical failure of the Khumbuz canal is shown in figure 3.

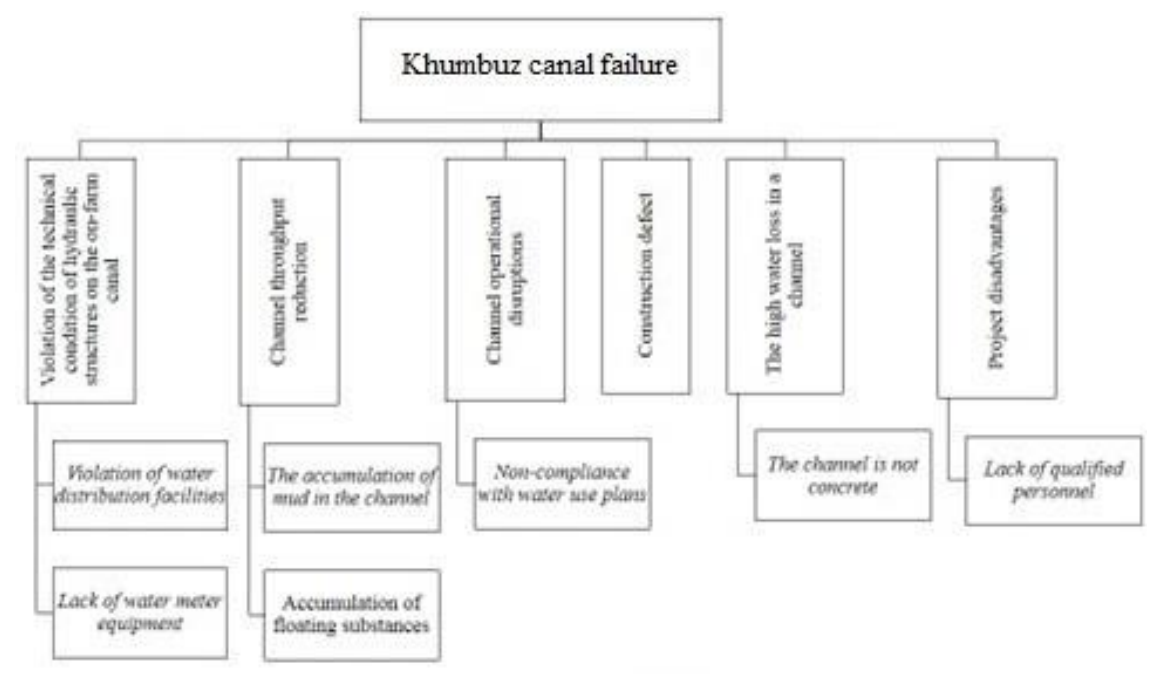

Fig. 3. Technical failure of Khumbuz canal

As a result of the study of the structure of the Khumbuz canal and hydraulic structures' condition, it was determined that repair work should be carried out to ensure its safe operation.

\section{Conclusions}

Based on the research conducted to ensure the reliable and safe operation of the Khumbuz canal and its hydraulic structures, the following recommendations can be made:

1. As a result of field observations conducted in the research channel, their technical condition was fully assessed.

2. Reconstruction of the canal with a length of $6 \mathrm{~km}$ (part from PK0 +00 to PK60 + 00), of which 2,568 km is making new concrete paving;

3. Reconstruction of hydraulic structures: 1 hydro post, 1 pipeline crossing, 1 barrier structure, and 6 water intake facilities;

4. Implementation of repaired hydraulic structures, including 1 main structure; 1 pipe crossing; 1 barrier structure; 6 water intake facilities, 6 pipe crossings, 1 barrier structure, 4 water intake facilities, and 1 road bridge;

5. Emergency (failure) condition of hydraulic structures is developed.

6. Conclusions and recommendations for the reliable and safe operation of hydraulic structures at the research facilities.

\section{References}

1. Balla D, Omar M, Maassen S, Hamidov A, Khamidov M Efficiency of duckweed (Lemnaceae) for the desalination and treatment of agricultural drainage water in 
detention reservoirs. Environmental Science and Engineering (Subseries: Environmental Science), pp.423-440, (2014)

2. Bazarov D, Uralov B, Matyakubov B, Vokhidov O, Uljaev F, Akhmadi M "The effects of morphometric elements of the channel on hydraulic resistance of machine channels of pumping stations"// IOP Conference Series: Materials Science and Engineering. (2020)

3. Matyakubov B, Begmatov I, Raimova I., Teplova G., (2020) "Factors for the efficient use of water distribution facilities"// Conf. Series: Materials Science and Engineering 883012050 doi: 10.1088 / 1757-899X / 883/1/012050.

4. Matyakubov B How efficient irrigation can ensure water supply in the Lower Amudarya basin of Uzbekistan, International Water and Irrigation, 23 (3), pp. 26-27, (2003)

5. Matyakubov B., Begmatov I., Mamataliev A., Botirov S., Khayitova M "Condition of irrigation and drainage systems in the Khorezm region and recommendations for their improvement"// Journal of Critical Reviews, Volume 7, Issue 5, pp.417 - 421, (2020)

6. Matyakubov B, Isabaev K, Yulchiyev D, Azizov S "Recommendations for improving the reliability of hydraulic structures in the on-farm network"// Journal of Critical Reviews, Volume 7, Issue 5, pp.376 - 379, (2020)

7. Matyakubov B, Mamatkulov Z, Oymatov R, Komilov U, Eshchanova G., "Assessment of the reclamation conditions of irrigated areas by geospatial analysis and recommendations for their improvement"//InterCarto InterGIS GI SUPPORT OF SUSTAINABLE DEVELOPMENT OF TERRITORIES Proceedings of the International conference. Volume 26, part 3 pp.229 - 239, (2020)

8. Begmatov I., Matyakubov B, Akhmatov D, Pulatova M Analysis of saline land and determination of the level of salinity of irrigated lands with use of the geographic information system technologies // InterCarto Inter GIS GI SUPPORT OF SUSTAINABLE DEVELOPMENT OF TERRITORIES, (2020)

9. Hamidov A, Khamidov M, Ishchanov J (2020) Impact of climate change on groundwater management in the northwestern part of Uzbekistan. Agronomy 10(8), 1173.

10. Ermatova D, Imomov S, Matmurodov F (2020) Mathematical modeling of the interaction of the main parts of a wheel tractor and the numerical determination of the operator's seat oscillation IOP Conference Series: Earth and Environmental Science, $614(1)$.

11. Khamidov M, Khamraev K, Isabaev K (2020) Innovative soil leaching technology: A case study from Bukhara region of Uzbekistan. IOP Conference Series: Earth and Environmental Science, 422 (1), 012118

12. Khamidov M, Matyakubov B, Isabaev K Substantiation of cotton irrigation regime on meadow-alluvial soils of the Khorezm oasis. Journal of Critical Reviews, 7 (4), pp.347-353, (2020)

13. Khamidov M, Khamraev K, Azizov S, Akhmedjanova G., Water saving technology for leaching salinity of irrigated lands: A case study from Vukhara region of Uzbekistan. Journal of Critical Reviews, 7 (1), pp.499-509, (2020)

14. Imomov S., Shodiev E., Tagaev V., Qayumov T., (2020) Economic and statistical methods of frequency maintenance of biogas plants. IOP Conference Series: Materials Science and Engineering, 883 (1).

15. Imomov S, Kholikova N, Alimova Z. Nuritov I, Temirkulova N (2019) Oil purification devices used in internal combustion engines. International Journal of Innovative Technology and Exploring Engineering, 9(1), 3103-3107. doi.org/10.35940/ijitee. A9141.119119. 
16. Marupov I, Imomov S, Ermatova D, Majitov J, Kholikova N, Tagaev V, Nuritov I Research of vertical forces for acting tractor unit. IOP Conference Series: Earth and Environmental Science, Volume 614, (2020)

17. Khamidov F, Imomov S, Abdisamatov O, Sarimsaqov M, Ibragimova G, Kurbonova $\mathrm{K}$ Optimization of agricultural lands in land equipment projects. Journal of Critical Reviews, 7 (11), pp.1021-1023, (2020)

18. Uralov B, Xidirov S, Matyakubov B, Eshonkulov Z, Norkulov B, Gayur A (2020) "River channel deformations in the area of damless water intake". IOP Publishing, IOP Conf. Series: Materials Science and Engineering 869 072014. doi:10.1088/1757899X/869/7/072014. 